\title{
A Strategic Planning Process Model for Developing Open Educational Resources
}

\author{
Shu-Hsiang Chen, Jaitip Nasongkhla, and J. Ana Donaldson
}

\begin{abstract}
Strategic planning processes are considered to be a powerful tool and guideline for helping all levels of Higher Educational Institutions (HEIs) to develop their strategic plan, and to find their competitive advantage and place within their environment. To date, very little research has been conducted on the strategic planning to support and foster open educational resources (OERs) development. The objective of this study was to develop a strategic planning process (SPP) model for Thailand HEIs based on the concept of university social responsibility (USR) for developing OER. The final strategic planning process (SPP) model was verified by subject matter experts, focus group interviews, and the results from the Index of Item-Objective Congruence (IOC) evaluation from higher education executive administrators. The development of this SPP Model serves as a toolkit for mapping out a strategic plan along with activities for aligning the concept of USR to the outcome and creating an OER strategic plan as output, which together can connect strategic planning to universities' sustainable effectiveness and success in the long term.
\end{abstract}

Index Terms - Strategic planning process model, SPP model, open educational resources, OER, university social responsibility, USR.

\section{INTRODUCTION}

Strategic planning is one of the key elements of successful management in higher education institutions (HEIs) [1] and is a "means of establishing major directions for the university, college/school or department" [2]. The strategic planning process relies on the theoretical framework of the business management theory as the management theorist Henri Fayol (1841-1925) described that planning as "examining the future, deciding what needs to be done, and developing a plan of action" (as cited in [3]), since planning is one of the fundamental and essential steps in every decision.

Strategic visionary actions and planning processes are a way to systematically plan the development of open education resources and practices for the future. Strategic planning processes are considered to be a powerful tool and guideline for helping all levels of HEIs to develop their strategic plan, and to find their competitive advantage and place within their environment. Therefore, it is essential to consider what components are needed for the strategic planning process for developing open educational resource strategies based on the concept of university social

Manuscript received May 2, 2017; revised September 15, 2017.

Shu-Hsiang Chen is with Chilitag Technology Co., Ltd., Kaohsiung city, Taiwan (e-mail: ava1019@gmail.com, avachen@chilitag.com.tw).

Jaitip Nasongkhla is with Chulalongkorn University, Bangkok, Thailand, (e-mail: jaitip.n@chula.ac.th).

J. Ana Donaldson was with University of Northern Iowa, Cedar Falls, IA 50613, USA (e-mail: ana.donaldson@cfu.net). responsibility. This will help Thailand HEIs move toward an openness knowledge-based economy, and the concept of university social responsibility can be facilitated with respect to an openness vision, mission, values, goals, and strategies for open educational resources (OERs) development and practice.

To date, very little research has been conducted on strategic planning to support and foster OERs development. As such, a good starting point for Thailand HEIs is to consider developing a clear strategic plan that is aligned with their current university practices in addition to creating services that can truly extend the use and development of OERs in HEIs. Accordingly, the objective of this study was to develop a strategic planning process (SPP) model for Thailand HEIs based on the concept of university social responsibility (USR) for developing OERs.

\section{LITERATURE REVIEW}

Although every strategic planning process model in the existing literature is uniquely designed to fit the specific needs of a particular higher education institution or organization, there are common components from each strategic planning process model. A review of selected strategic planning process models is discussed in the following section. Strategic planning process models have been proposed in a variety of contexts including corporation, not-for- profits, and for higher education. To limit the scope of the study and to meet the purpose, this study reviewed the existing SPP models that have been proposed for a higher education context and selected the following model for future discussion.

\section{A. Kotler and Murphy [4] SPP Model}

In 1981, Kotler and Murphy [4] proposed a strategic planning process model that suggests a college or university carefully examine its environment, reviews its major resources, and formulates new and appropriate goals followed by strategy development in the most cost effective way. They further suggested the SPP model should be completed at each major institutional level and should formulate strategic plans that impact the future of that college or university. In their study, they used Beloit College as an example that followed along their purposed SPP model. The major components in the Kotler and Murphy model include: (1) environmental analysis, (2) resource analysis, (3) goal formulation, (4) strategy formulation, (5) organization design, and (6) systems design (Fig. 1). Each component has sub-components to help users / readers to further explore based on their context. They suggested that higher education 
institutions should first examine the environmental and resources factors, second formulate the goals and follow by strategy development for reaching the goals, and third design the organizational structure and systems. This model seems to be generalized enough and able to apply to different contexts in college or university settings. However, the implementation of this process was not explicitly addressed.

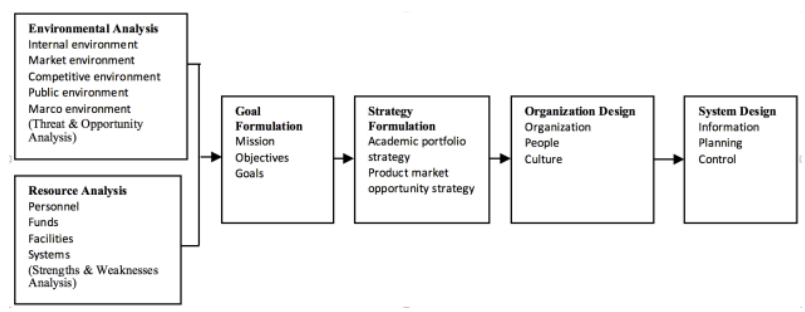

Fig. 1. Strategic planning process model [4] p. 472.

\section{B. The Research Foundation [5] SPP Model}

The Research Foundation [5] at the State University of New York developed a guideline to provide the Research Foundation (RF) leaders a strategic planning methodology and provided terms and steps that should be conducted during the strategic planning process. This SPP Model (Fig. 2) aims to provide terminology, guidance, and direction to complete continuous strategic planning at the RF at the State University of New York. There are seven steps that were developed including: (1) gather and analyze information (external, internal, and market); (2) identify critical issues facing the organization; (3) develop a strategic vision statement; (4) review the mission; (5) develop strategic goals; (6) formulate strategic for each; and (7) develop annual objectives based on the strategic plan.

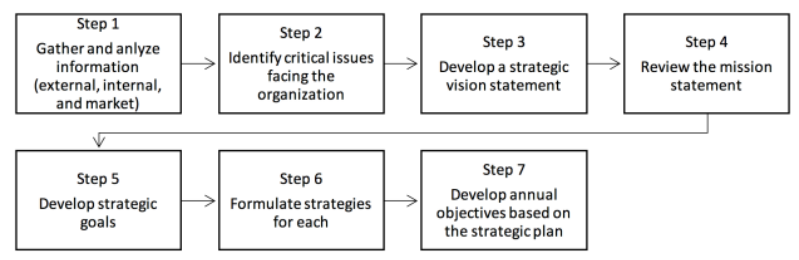

Fig. 2. Strategic planning process [5].

\section{Lerner [6] Strategic Planning Process Model}

Lerner [6] provided an overview of the strategic planning process (Fig. 3) that intends to help understand the concept of strategic planning and its process. The author explained the challenges facing California Higher Education and the importance of examining the strategic planning process. Although every SPP model is uniquely designed to fit the specific needs for a particular university, the SPP model that Lerner proposed includes most of steps from the previous SPP models. The components in Lerner's model are (1) mission / vision, (2) strategic issues - gaps analysis, benchmarking, environmental scan and SWOT, (3) deliberate / intended strategies - emergent strategies, (4) ongoing strategic programming, and (5) strategic learning and strategic thinking. This SPP model was developed to meet the needs of the California State University (CSU) system. By following along this SPP model, CSU aimed to preserve the shared governance, support individual campuses with unique needs, and protect and regenerate superior faculty. This SPP model was generalized enough for CSU to follow along. However, the implementation and strategic plan monitoring were not explicitly addressed.

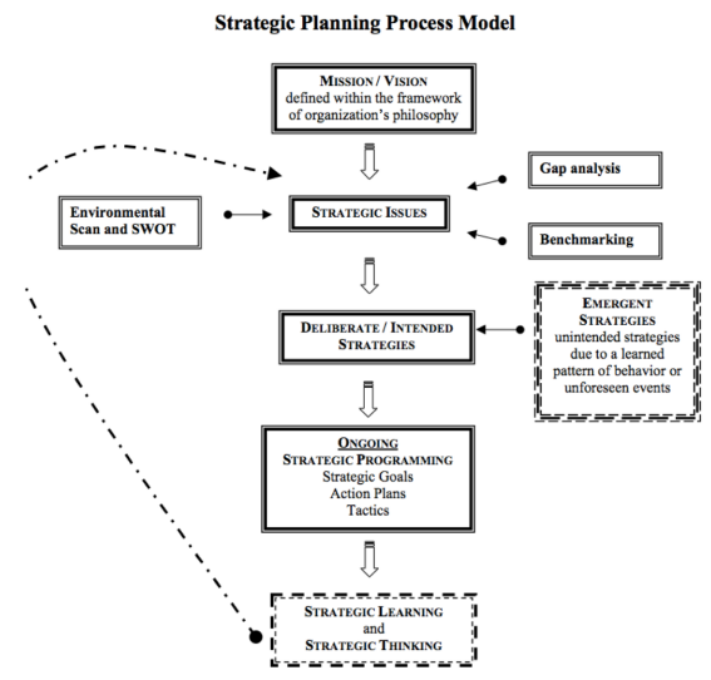

Fig. 3. Strategic planning process model [6] p. 13.

\section{Paris [2] Strategic Planning Model}

The SPP model in Fig. 4 reflects the strategic planning process that was used at the University of Wisconsin Madison. The components of this SPP model include (1) mission, (2) operating principles, (3) vision, (4) situational analysis, (5) strategic priorities, (6) one year action planning, budgeting, and process improvement, and (7) periodic checks. Each component provides useful questions that help planners or administrators to frame a final outcome for the strategic plan. The internal and external analyses were critical steps in this SPP model for UW-Madison to meet the needs and expectations from the stakeholders and also to examine the requirement as the foundation for planning.

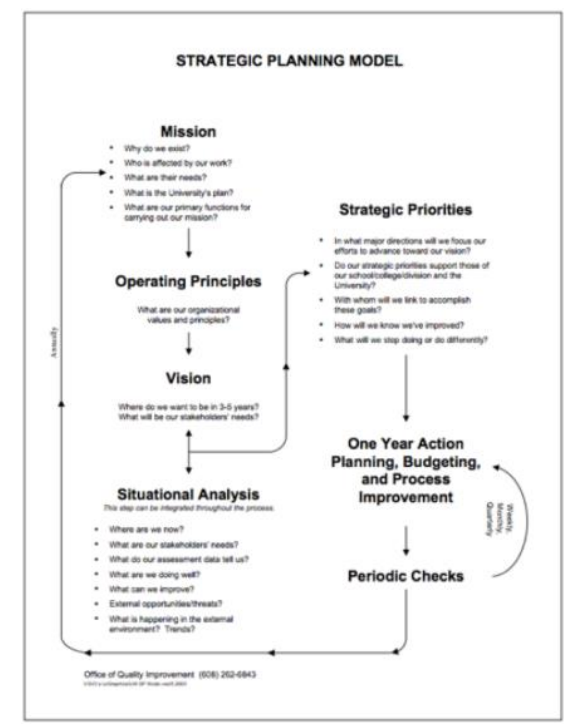

Fig. 4. Strategic planning process model [2] p. 3.

\section{E. Pisel [7]-[9] SPP Model for Distance Education}

Pisel [7]-[9] conducted research on the strategic planning process model for distance learning in higher education. After refining and validating the initial proposed model, [7], [8] proposed a finalized SPP model (Fig. 5) that consists of a 10-phases including: (1) planning initiation, (2) planning 
guidance and scheduling, (3) analyses, (4) mission refinement, (5) assumptions, (6) strategy development and course of action, (7) functional analyses, (8) implementation, (9) assessment, and (10) periodic review. This SPP model provides a comprehensive collection of ongoing activities and processes that individuals should be aware of during the
SPP model implementation. The course of action (COA) was proposed as a key driver for the institution to fill the gaps by taking action. This is a good example to consider for how a SPP model can be developed to meet the context of OER and USR for this study.

TABLE I: ANALYSIS OF SELECTED SPP MODEL

\begin{tabular}{|c|c|c|c|c|}
\hline Model & Explanation & Stages & Benefits & Drawbacks \\
\hline [2] & $\begin{array}{l}\text { This SPP Model was developed from the office of quality } \\
\text { improvement and has been used in a variety of department, } \\
\text { offices, and colleges on the UW-Madison campus. The } \\
\text { internal and external analyses were critical steps in this SPP } \\
\text { model for UW-Madison to meet the needs and expectations } \\
\text { from the stakeholders and also to examine the requirement as } \\
\text { the foundation for planning. }\end{array}$ & $\begin{array}{l}\text { Strategy } \\
\text { envision and } \\
\text { formulation, } \\
\text { situational } \\
\text { analysis. }\end{array}$ & $\begin{array}{l}\text { Generalized enough to apply } \\
\text { to different contexts and the } \\
\text { details of examining the } \\
\text { strategic issues from } \\
\text { different perspectives. }\end{array}$ & $\begin{array}{l}\text { The strategy } \\
\text { implementation was not } \\
\text { explicitly addressed } \\
\text { although strategic learning } \\
\text { and thinking was reflected } \\
\text { back to strategic issues. }\end{array}$ \\
\hline [4] & $\begin{array}{l}\text { This SPP model was proposed and used at Beloit College as } \\
\text { an example to follow along the purposed SPP model process. } \\
\text { This model seems to be generalized enough and to be able to } \\
\text { apply to different contexts in college or university settings. }\end{array}$ & $\begin{array}{l}\text { Situational } \\
\text { analysis, } \\
\text { strategy } \\
\text { formulation }\end{array}$ & $\begin{array}{l}\text { Generalized enough to apply } \\
\text { to different contexts in } \\
\text { college or university } \\
\text { settings. }\end{array}$ & $\begin{array}{l}\text { The strategy } \\
\text { implementation was not } \\
\text { explicitly addressed. }\end{array}$ \\
\hline$[5]$ & $\begin{array}{l}\text { This SPP Model was developed by the research foundation at } \\
\text { the State University of New York to provide terminology, } \\
\text { guidance, and direction to complete continuous strategic } \\
\text { planning at the RF. }\end{array}$ & $\begin{array}{l}\text { Situational } \\
\text { analysis, initial } \\
\text { assessment, } \\
\text { strategy } \\
\text { formulation, }\end{array}$ & $\begin{array}{l}\text { Generalized enough to apply } \\
\text { to different content in } \\
\text { general contexts. }\end{array}$ & $\begin{array}{l}\text { The strategy } \\
\text { implementation was not } \\
\text { explicitly addressed. }\end{array}$ \\
\hline [6] & $\begin{array}{l}\text { This SPP model was developed to meet the needs of the } \\
\text { California State University (CSU). By following along this } \\
\text { SPP model, CSU aims to preserve the shared governance, } \\
\text { support individual campuses with unique needs, and protect } \\
\text { and regenerate superior faculty. This SPP model was } \\
\text { generalized enough for CSU to follow along. However, the } \\
\text { implementation and strategic plan monitoring were not } \\
\text { explicitly addressed. }\end{array}$ & $\begin{array}{l}\text { Strategy } \\
\text { envision and } \\
\text { formulation, } \\
\text { strategy issues } \\
\text { analysis, }\end{array}$ & $\begin{array}{l}\text { Generalized enough to apply } \\
\text { to different contexts and } \\
\text { periodic checks at the end } \\
\text { for better improvement. }\end{array}$ & $\begin{array}{lr}\text { The } & \text { strategy } \\
\text { implementation } & \text { strategy } \\
\text { was not } & \text { explicitly } \\
\text { addressed. } & \end{array}$ \\
\hline [7] & $\begin{array}{l}\text { This SPP model was developed and conducted for distance } \\
\text { learning in higher education. This SPP model provides a } \\
\text { comprehensive collection of ongoing activities and processes } \\
\text { that individuals should be aware of during the SPP model } \\
\text { implementation. The course of action (COA) was proposed as } \\
\text { a key driver for institutions to fill the gaps by taking action. } \\
\text { This is a good example to consider how SPP model can be } \\
\text { developed to meet the context of OER and USR for this study. }\end{array}$ & $\begin{array}{l}\text { Initial planning } \\
\text { and assessment, } \\
\text { situational } \\
\text { analysis, } \\
\text { strategic } \\
\text { envision and } \\
\text { formulation, } \\
\text { strategy } \\
\text { implementation, } \\
\text { and strategy } \\
\text { assessment }\end{array}$ & $\begin{array}{l}\text { Covered the comprehensive } \\
\text { collection of } \begin{array}{r}\text { ongoing } \\
\text { processes, } \\
\text { activities, } \\
\text { implementation, } \\
\text { periodic review. }\end{array}\end{array}$ & $\begin{array}{l}\text { Details provided, but may } \\
\text { be difficult to execute in } \\
\text { reality or may need to make } \\
\text { adjustments based on the } \\
\text { applying context. }\end{array}$ \\
\hline [10] & $\begin{array}{l}\text { This SPP model was adopted by Oztemel et al (2009) as a road } \\
\text { map for creating a strategic plan. The proposed strategy was } \\
\text { later implemented at Sakarya University and produced a very } \\
\text { good and implementable strategic plan. }\end{array}$ & $\begin{array}{l}\text { Initial planning } \\
\text { and assessment, } \\
\text { situational } \\
\text { analysis, } \\
\text { strategy } \\
\text { formulation, } \\
\text { strategy } \\
\text { implementation, } \\
\text { and strategy } \\
\text { monitoring. }\end{array}$ & $\begin{array}{l}\text { Clear and generalized } \\
\text { enough to apply to different } \\
\text { contexts as a road map. }\end{array}$ & $\begin{array}{l}\text { Each component may take } \\
\text { time to execute especially } \\
\text { the one involved with } \\
\text { budgeting. }\end{array}$ \\
\hline
\end{tabular}

TABLE II: RESEARCH PROCEDURES

\begin{tabular}{|c|c|c|c|}
\hline Procedure & Purpose & Instrument & Output \\
\hline 1 & $\begin{array}{l}\text { To conceptualize existing literature in open educational } \\
\text { resources, university social responsibility, social } \\
\text { entrepreneurship, and strategic planning to draft a } \\
\text { conceptual strategic planning process (SPP) Model for } \\
\text { Asian Higher Education Institutions. }\end{array}$ & Systematic Literature Review & "Conceptual SPP Model \\
\hline 2 & $\begin{array}{l}\text { To conduct a qualitative opinion interview and document } \\
\text { review with SMEs regarding the conceptual SPP model }\end{array}$ & Subject Matter Experts & $\begin{array}{l}\text { Interview and document analysis } \\
\text { results }\end{array}$ \\
\hline 3 & $\begin{array}{l}\text { To integrate finding from step } 2 \text { in order to draw } 1^{\text {st }} \text { Draft } \\
\text { SPP model }\end{array}$ & & $1^{\text {st }}$ SPP Model \\
\hline 4 & $\begin{array}{l}\text { To discuss and confirm the components of } 1^{\text {st }} \text { SPP model } \\
\text { and survey results with focus group experts }\end{array}$ & Focus Group & Focus group data \\
\hline 5 & $\begin{array}{l}\text { To integrate findings from step } 4 \text { in order to finalize the } \\
\text { components of the SPP Model }\end{array}$ & & \\
\hline 6 & $\begin{array}{l}\text { To review and validate a possibility of implementing SPP } \\
\text { model and its components with experts }\end{array}$ & $\begin{array}{l}\text { Index of Item-Objective Congruence } \\
\text { (IOC) Evaluation }\end{array}$ & Final SPP Model \\
\hline
\end{tabular}




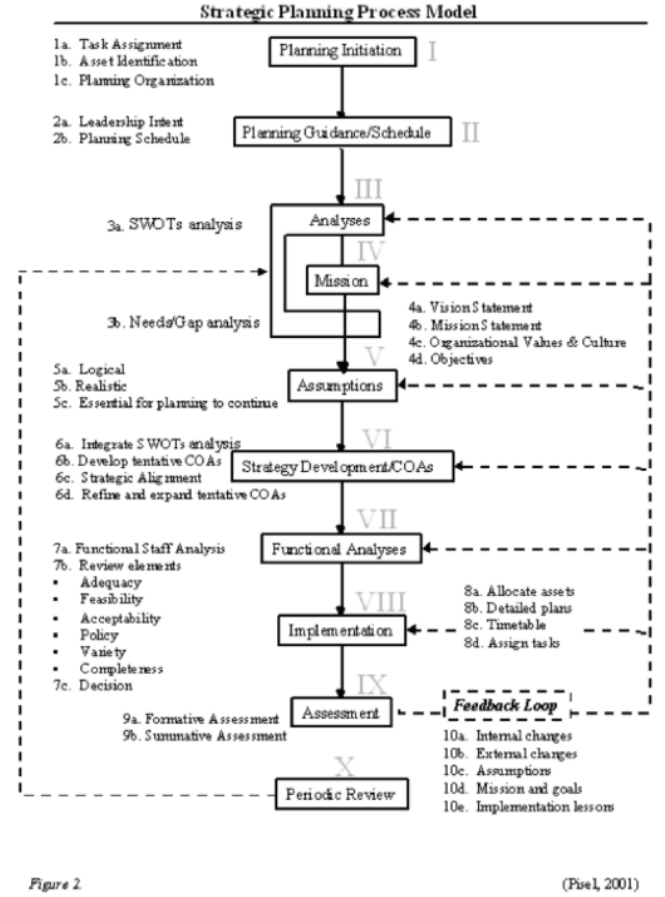

Fig. 5. Strategic planning process model for distance education [8] p. 4.

\section{F. Strategic Planning Workbook [10]}

A study [1] adopted the [10] (Fig. 6) as a road map to develop a series of pre-planned activities and the strategy for implementation with the assessment of organizational values, mission, vision, and strategy at Sakarya University in Turkey.

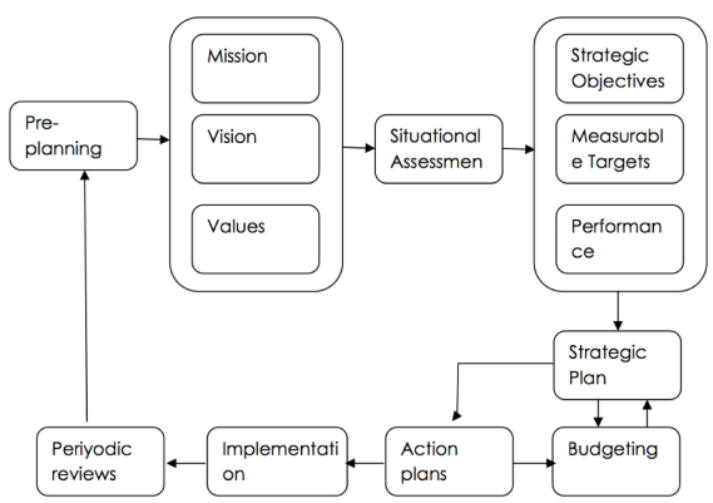

Fig. 6. Strategic process model [10].

According to discussion above, a common characteristic of reviewed SPP models is illustrated in Table I. The benefits and drawbacks were analyzed based on the [11] guidelines.

\section{RESEARCH Methodology}

This study used a qualitative methodology. The nature of a qualitative study allows for collection and analysis of open-ended data, providing insights into the interpretations people have of specific problems or situations [12]. The research procedures in this study were as follows (Table II).

\section{RESUlts}

\section{A. Conceptual SPP Model}

Based on the review and synthesis of the strategic planning process model above, a conceptualized SPP model was developed and presented at an international conference [13]. The proposed conceptual SPP Model (Fig. 7) consists of six stages including (1) envisioning, (2) social situational analysis, (3) strategy formulation, (4) taking action, (5) evaluating, and (6) sustaining.

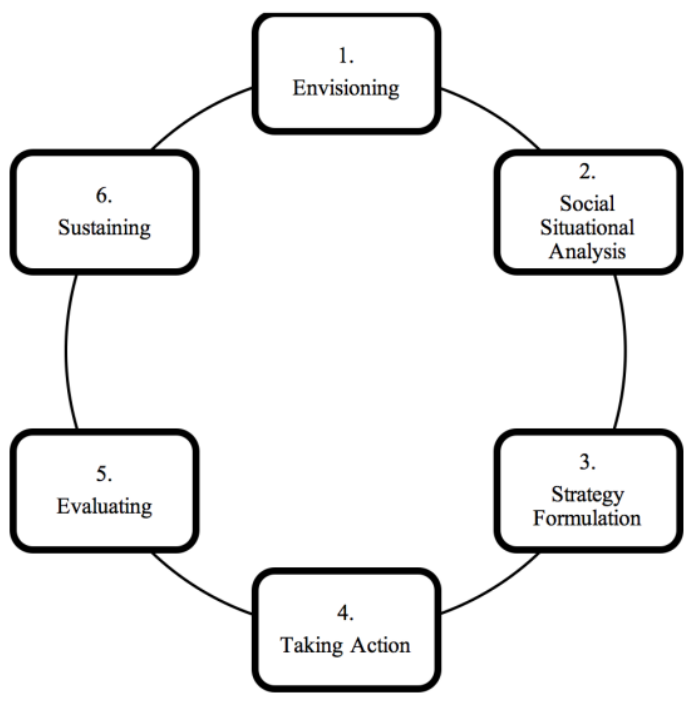

Fig. 7. Conceptual SPP model.

\section{B. Subject Matter Experts (SMEs) Interview}

The demographic profile of SMEs included four female $(44.44 \%)$ and five males $(55.56 \%)$. Six out of nine SMEs were from Bangkok regions; followed by one from Central Thailand $(11.11 \%)$, one in Northern Thailand $(11.11 \%)$, and one in Southern Thailand $(11.11 \%)$. These SMEs provided their opinions, comments, and suggestions on the documents. The SMEs' opinions, comments, and suggestions were integrated to $1^{\text {st }}$ version of SPP Model (Fig. 8).

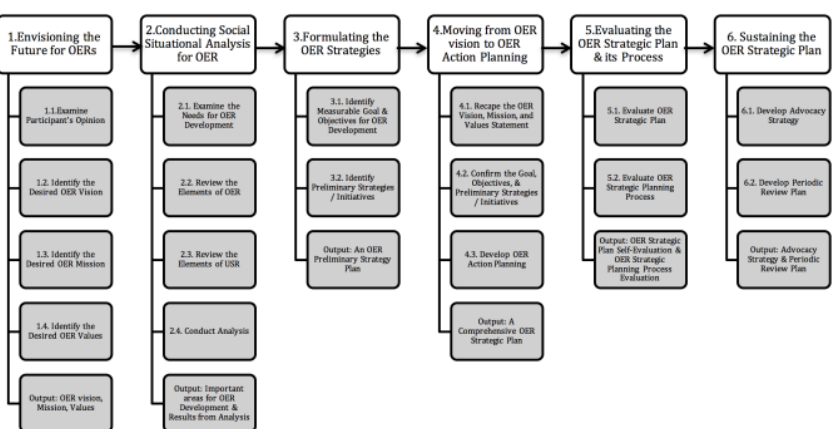

Fig. $8.1^{\text {st }}$ version of strategic planning process model.

\section{Focus Group}

Focus group interviews and discussion was carried out. Five SMEs from Thailand attended a focus group interview. They provided their opinions, comments, and suggestions based on the focus group's interview agenda. The results leaded to the finalized SPP Model.

\section{Index of Item-Objective Congruence (IOC) Evaluation}

IOC evaluation was conducted with experts who attended the focus group interview and provided the final consensus of the SPP model. The majority of experts who have attended the focus group accepted and approved the final strategic 
planning model with only a minor wording revision as results shown on Table III.

TABLE III: SPP MODEL IOC EVALUATION

\begin{tabular}{|c|c|c|}
\hline Item & IOC Mean Score & Interpret \\
\hline $\begin{array}{l}\text { Assess Strategic Plans (University, } \\
\text { Faculty, and Department) }\end{array}$ & 0.6 & Accepted \\
\hline Assess University KPI & 1 & Accepted \\
\hline $\begin{array}{l}\text { Examine University Policy and } \\
\text { Strategy in relation to USR and OER }\end{array}$ & 1 & Accepted \\
\hline $\begin{array}{l}\text { Examine Current USR and OER } \\
\text { practices }\end{array}$ & 1 & Accepted \\
\hline $\begin{array}{l}\text { 1. Envisioning the Future for } \\
\text { OERs }\end{array}$ & 0.6 & Accepted \\
\hline $\begin{array}{l}\text { 2. Conducting Social } \\
\text { Situational Analysis for } \\
\text { OER \& USR }\end{array}$ & 0.8 & Accepted \\
\hline $\begin{array}{l}\text { 3. Formulating the OER } \\
\text { Strategies }\end{array}$ & 0.8 & Accepted \\
\hline $\begin{array}{l}\text { 4. Moving from OER Vision to } \\
\text { OER Action Planning }\end{array}$ & 0.6 & Accepted \\
\hline $\begin{array}{l}\text { 5. Evaluating the OER } \\
\text { Strategic Plan and the } \\
\text { Process }\end{array}$ & 0.6 & Accepted \\
\hline $\begin{array}{l}\text { 6. Sustaining the OER Strategic } \\
\text { Plan }\end{array}$ & 0.8 & Accepted \\
\hline OER Strategic Plan & 1 & Accepted \\
\hline USR Outcomes & 1 & Accepted \\
\hline
\end{tabular}

\section{E. Final Strategic Planning Process Model}

The final strategic planning process (SPP) model (Fig. 9) was verified from subject matter experts, focus group interviews, and IOC evaluation from higher education executive administrators. Each component was discussed in the following.

\section{1) Input}

The input in this section is to conduct an internal assessment. This includes reviewing participant's current strategic plans: university, faculty, and department strategic plan, university key performance indicators, university policy and strategy in relation to USR, and review the current USR, OER, and academic services practice.

\section{2) Process}

This strategic planning process consists of six stages that help executive administrators in higher education institution (HEI) particularly at a department level, to develop open educational resources strategic plan based on the concept of University Social Responsibility.

Stage 1: Envisioning the Future for Open Educational Resources (OERs)

Envisioning the future and developing the desired vision, mission and values is an important stage to ensure the overall success of a strategic plan. In this stage, participants provide their opinions and understand the importance of using, creating, and sharing open educational resources in order to develop their desired future objectives. Their opinion will lead to identifying the desired vision, mission, and values statement of OER in their context.

Stage 2: Conducing Social Situational Analysis for Open Educational Resources (OERs)

Assessing and analyzing the social situation is a very important stage for a successful strategic plan. This involves examining the needs and gaps of the department, reviewing the elements of OERs and USR, and conducting analysis of a department's internal assessment such as strengths, weaknesses, opportunities, and threats (SWOT). Participants also need to understand the external environment such as political and demographic change, social needs and impact, environmental trends, and technology trends. This information will be collected through various activities and other analytical techniques. The outcome for this stage is to help participants to recognize the sustainable condition in order to meet the desired vision, mission, and values statement of OERs.

Stage 3: Formulating the Open Educational Resources (OERs) Strategies

In order to answer the main question of how to achieve the goals of using, creating, and sharing open educational resources, it is important to develop a set of measurable goals, objectives, and preliminary strategy / initiatives to address the significant critical issues of the future.

Stage 4: Moving from OER vision to OER Action Planning

In order to move from OER vision to OER action, it is important to move down to specific steps that will achieve the strategic goal and objectives. The steps in this stage are: (1) to recap the vision, mission, and values statement from stage 1, (2) to confirm the goals, objectives and preliminary strategies / initiatives from stage 2, and (3) to develop action plan towards operations, procedures, and processes.

Stage 5: Evaluating the OER Strategic Plan and its Process

In this stage, it is very important to conduct an evaluation that helps participants to assess and evaluate the results from previous stages to see if the vision and mission have stayed consistent.

Stage 6: Sustaining the OER Strategic Plan

To truly sustain the strategic planning process, developing advocacy and a periodic review will enable the participants to adapt to short-term strategies while maintaining their long-term strategic vision.

\section{3) Output}

The output in this section is to produce a comprehensive OER Strategic Plan

\section{4) Outcome}

The expected outcome in this section is the influential outcome after implementing the comprehensive OER strategic plan that fulfills the USR SCOPE (Social, Sub-Social, Cognitive, Organizational, Philanthropic, Economic, Ethic, Educational, and Environmental) Impacts.

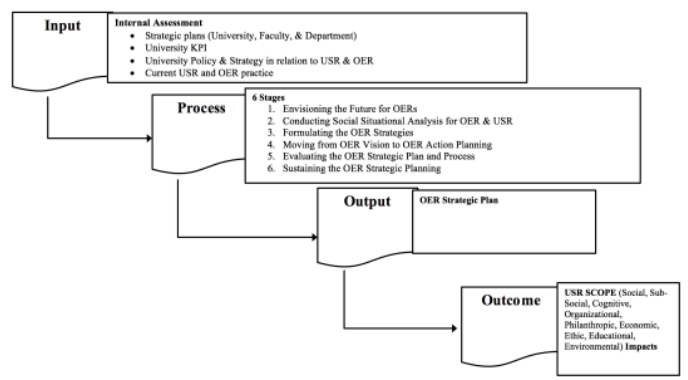

Fig. 9. Final strategic planning process (SPP) model.

\section{IMPLICATIONS AND CONCLUSION}


Strategic planning is a complex and time-intensive process. It is a process that does and should allow access for stakeholders from all levels of the higher education system. The potential of strategic planning will not be realized until there is a strong and realistic strategic plan for the future. Such a plan must focus strongly on the details of how reform can and will be implemented, how does this along with the creation of an USR analysis for not only university, but also the community and society.

The development of this SPP Model serves as a toolkit for mapping out a strategic plan along with activities for aligning the concept of USR to the outcomes and creating an OER strategic plan as output, which together can connect strategic planning to universities' sustainable effectiveness and success in the long term. The finding of this study has facilitated the concept of university social responsibility in the creation of an OER vision, mission, goals, and strategies. The previous research [15]-[20] in the area of USR components was taken into consideration when conducting the strategic planning. By considering a variety of USR practices in each component, Asian HEIs could fulfill their social movement and could present their evidence of commitment to stakeholders and the community throughout the openness of knowledge creation and transformation. This approach has supported the existing literature [19] in the area of the key feature of social responsibility for a university to follow. In addition, this brings a further level of innovation to sustain future educational frameworks.

Moreover, the findings of this study provide benefits to scholars in the field of educational technology or university policy and administration by expanding existing educational strategy planning and moving further to the educational policy development focus. In addition, other scholars may use this model as a toolkit to plan their OER strategic plan based on the concept of university social responsibility according to their own context. This study raises awareness by linking USR and OER practices for different types of universities toward the establishment of social responsible universities that move toward building the nations open knowledge-based society. In a specific case, the university policy maker may focus on the development of each component of USR and with the proper funding realize support for the country moving toward an open knowledge-based society.

In summary, this study contributes to current research in a practical way. The research results bring a new perspective to the research conducted on OER and USR in a Thai context. This may encourage a Thai university to expand its roles and services with a managerial emphasis; to take their role as a social entrepreneur and move to further levels of achievement and responsibility with both individuals and institutions in order to fulfill positive social practice, social movement, and social changes throughout the open educational resources creation and practices.

\section{REFERENCES}

[1] E. Oztemel, C. Kubat, and H. Taskin, "A road map for strategic planning in higher education institutions," in Proc. 6th Research/Expert Conference with International Participations: Quality, 2009, pp. 4-7.
[2] K. A. Paris. Strategic planning in the university [Online]. Available: http://www.cuhk.edu.hk/u-planning-office/documents/other-strategicplanning/paris-2003_strat-plan-in-u.pdf

[3] J. C. Schmidt and M. Laycock. Understanding the theory and process of strategic development: Theories of strategic. [Online]. Available https://www.healthknowledge.org.uk/public-health-textbook/organisat ion-management/5d-theory-process-strategy-development/strategic-pl anning

[4] P. Kotler and P. E. Murphy, "Strategic planning for higher education," The Journal of Higher Education, vol. 52, pp. 470-489, Sep. 1981.

[5] The Research Foundation. (December 2008). Strategic planning. Research foundation methodology. [Online]. Available https://portaltest.rfsuny.org/portal/page/portal/The\%20Research\%20F oundation\%20of\%20SUNY/home/What_we_do/strategic_planning/st rategic_planning_methodology.pdf

[6] A. L. Lerner. (July 1999). A strategic planning primer for higher education. [Online]. Available: http://www.fgcu.edu/provost/files/strategic_planning_primer.pdf

[7] K. P. Pisel. "The validation of a detailed strategic planning process model for the implementation of distance education in higher education," Old Dominion University, Norfolk, VA., 2001.

[8] K. P. Pisel, "A strategic planning process model for distance education," Online Journal of Distance Learning Administration, vol. 11, pp. 199-215, 2008.

[9] K. P. Pisel and J. M. Ritz, "Strategy for planning, designing, and managing distance and distributed learning at the university," Distance and Distributed Learning Environments: Fifty-first yearbook of the Council on Technology Teacher Education, New York: Glencoe McGraw-Hill, pp. 35-64, 2005.

[10] N. Lake, The Strategic Planning Workbook; Kogan Page Publishers, 2006.

[11] O. Jurevicius. (February 2013). Strategic management and strategic planning. Strategic Management Insight. [Online]. Available: http://www.strategicmanagementinsight.com/topics/strategic-manage ment-planning.html

[12] J. W. Creswell, "Research design: Qualitative, quantitative, and mixed methods approaches," Sage Publications, Inc, 2009.

[13] S.-H. Chen, J. Nasongkhla, and J. A. Donaldson, "From vision to action: A strategic planning process model for open educational resources," Procedia-Social and Behavioral Sciences, vol. 174, pp. 3707-3714, Feb 2015

[14] R. C. Turner and L. Carlson, "Indexes of item-objective congruence for multidimensional items," International Journal of Testing, vol. 3, pp. 163-171, 2003

[15] AUN. AUN USR and S: University social responsibility and sustainability. http://www.aunsec.org/pdf/aunwebsite/usrsppocketbook.pdf

[16] A. Esfijani, F. K. Hussain, and E. Chang, "An approach to university social responsibility ontology development through text analyses," in Proc. 5th International Conference on Human System Interactions (HSI), pp. 1-7, 2012.

[17] J. Reiser. (2007). Managing university social responsibility. International Sustainable Campus Network: Best Practices - Future Challenges. [Online]. Available: http://www.international-sustainable-campus-network.org/view-docu ment/108-panel-b1-juan-reiser-pontificia-universidad-catolica-del-per

[18] L. Tetrevova and V. Sabolova, "University stakeholder management and university social responsibility," WSEAS Transactions on Advances in Engineering Education, vol. 7, pp. 224-233, July, 2010.

[19] F. Vallaeys, (May 2013). Defining social responsibility: A matter of philosophical urgency for university. Global University Network for Innovation. [Online]. Available: http://www.guninetwork.org/resources/he-articles/defining-social-resp onsibility-a-matter-of-urgency-for-philosophy-and-universities

[20] R. Vasilescu, C. Barna, M. Epure, and C. Baicu "Developing university social responsibility: A model for the challenges of the new civil society," Procedia-Social and Behavioral Sciences, vol. 2, pp. 4177-4182, 2010.

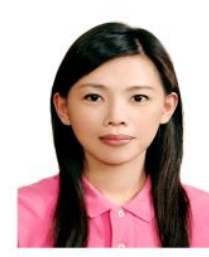

Shu-Hsiang Chen is currently working as ASEAN marketing consultant at Chilitag Technology Co., Ltd. Kaohsiung City, Taiwan. She is also working as adjunct assistant professor in the National Kaohsiung First University of Science and Technology, Taiwan. Her current research focus on open educational resources, technology integration into business and education, and university social responsibility. 


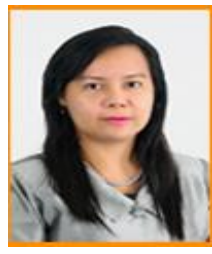

Jaitip Nasongkhla is an associate professor, heads of the Department of Educational Technology and Communications, and the director of innovative network of Educational Technology Research Center (iNet), Faculty of Education, Chulalongkorn University, Bangkok, Thailand, with expertise in educational technology, teacher education, and

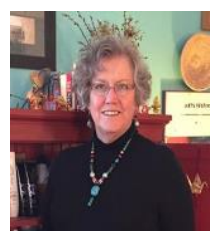

J. Ana Donaldson is past president of association for Educational Communications and Technology (AECT), and retired associate professor of instructional technology at University of Northern Iowa, USA, with expertise in engaging the online learner, educational technology, and adult education. 